\title{
Maiden Partisan Rural Local Government Elections: Bangladesh Experience
}

\author{
Md. Mashiur Rahman (Corresponding author) \\ PhD Student, Student ID: BL15216001 \\ School of Public Affairs, University of Science and Technology of China (USTC) \\ 96 Jinzhai Road, Hefei 230026, Anhui, P. R. China \\ Assistant Professor, Department of Public Administration \\ Comilla University, Comilla-3503, Bangladesh \\ Email: mashiur@mail.ustc.edu.cn
}

\author{
Salma Nasrin \\ Master student, Student ID: SL16216046 \\ School of Public Affairs, University of Science and Technology of China (USTC) \\ 96 Jinzhai Road, Hefei 230026, Anhui, P. R. China
}

Received: January 17, 2017 Accepted: February 15, 2017 Published: February 19, 2017

doi:10.5296/jpag.v7i1.10636 URL: http://dx.doi.org/10.5296/jpag.v7i1.10636

\begin{abstract}
A paradigm shift in the political system has been taken in Bangladesh on 12 October, 2015 with the final approval by the Cabinet to hold local polls on partisan basis. The long historical practice of non-partisan local polls has been shifted to first ever partisan poll that brought major challenges for the existing confrontational political parties of Bangladesh. Ruling Bangladesh Awami League considered demonstrating its popularity at grass-root level and controlled all political institutions through this election while Bangladesh Nationalist Party had opposed these partisan local government elections as a political trick with an ill motive by the government. For the first time in Independent Bangladesh, $9^{\text {th }}$ Union Parishad $^{\mathrm{i}}$ (UP) election held on partisan basis at six phases across the country from March to June 2016. The article tried to explore the experiences of this maiden partisan UP polls and what are the immediate consequences on the local governance as well as electoral system through reviewing secondary materials specially the Daily Newspapers. Unfortunately massive
\end{abstract}


violence, record deaths and uncontested elected Chairman, election frauds \& irregularities, reluctant role of Election Commission, strong dominance of ruling party over electoral system were common phenomena in this maiden partisan election.

Keywords: Local government, Union parishad, Partisan election, Election commission

\section{Introduction}

\subsection{A Brief Statement of Rural Local Government in Bangladesh}

Local governments in the Indian subcontinent have a long history. Its nature and structure was determined and reshaped by the then ruling party from time to time (Tepper, 1996). During the pre-Mughal era, 'Village Councils' is found in the rural village that is village-based local governments and each village used to run its own affairs (Quddusi, 2016, Rahman, 1988). During the medieval age, village administration was organised under the 'Village Panchayat' and it was mainly responsible for collecting the revenues, maintaining law and order situations, superintending education, irrigation, religious rituals, and moral behaviours of the villagers (Quddusi, 2016; Siddiqui, 2005; Rahman, 1988). Later, during the Mughal period, 'Sarkar' and 'Pargana' became the nerve centres of general and revenue administration under local government (Siddiqui, 2005). In the British era, the British abolished the 'Pargana' and 'Panchayat' systems; the civil and criminal courts became the basis of local administration and the local landlords became the local rulers (Siddiqui, 2005; Rahman, 1988). Through the Chawkidari Act of 1870, the British Government tried to revive the previous Panchayat system (Quddusi, 2016). Under the Local Self-Government Act of 1885, a three-tier local government system came into operation: 'District Board' for district, 'Local Board' for sub-division, and 'Union Committee' at the village level (Rahman, 1988). Through the enactment of the Bengal Village Self-Government Act of 1919, the former three-tier rural local government system was replaced by a two-tier system consisting of 'Union Board' and 'District Board' (Quddusi, 2016; Siddiqui, 2005).

During the Pakistan period, President Ayub Khan introduced a new model of local government system popularly known as 'Basic Democracy' that consists of four-tier local government system comprising 'Union Council', 'Thana Council', 'District Council', and 'Divisional Council' (Siddiqui, 2005; Tepper, 1996). After the liberation war of Bangladesh, the Presidential Order No. 7 of 1972 dissolved all existing local government authorities, the government appointed designated committees to replace the defunct committees (Siddiqui, 2005). The Presidential Order No. 22 specified that each 'Union' composed of several villages would be divided in three Wards; three 'Union Parishad (UP)' members would be elected from each Ward ${ }^{\mathrm{ii}}$. Besides, provisions were made for the Chairman and Vice Chairman to be directly elected by all eligible voters living within a UP. During President Zia regime, the Local Government Ordinance of 1976 introduced again a three-tier local government system: 'Union Parishad', 'Thana Parishad', and 'Zila Parishad'iii (Siddiqui, 2005). The structure and functions of the UP remained almost the same as they were under the Presidential Order No. 22, with the exceptions that the post of the Vice Chairman was 
abolished and four additional nominated members (two from women and another two from peasants) were included. In 1982, 'Thana Parishad' had been replaced by 'Upazila Parishad $(U Z P)^{\text {,iv }}$ during president Ershad regime (Siddiqui, 2005; Ahmed, 1991).

After the revival of parliamentary system of government in 1991, the first Khaleda Zia government abolished the Upazila system. In 1997, Sheikh Hasina government introduced four-tier rural local government system: 'Gram Parishad' at village level, 'Union Parishad' at union level, 'Upazila Parishad' at thana level, and 'Zila Parishad' at district level (Quddusi, 2016; Siddiqui, 2005). One significant addition of this government was holding of election in reserved women seats at UPs. After the regime change, Khaleda Zia government replaced 'Gram Parishad' with 'Gram Sarker' at the village level (Quddusi, 2016). After lot of experiment by the various governments, three tiers of rural local government is existed at present i.e. 'Zila Parishad' at district level, 'Upazila Parishad (UZP)' at thana level, 'Union Parishad' at union level. It is true that the Union Parishads gradually lost their significance in their administrative and political role they used to play from the ancient to the British period (Quddusi, 2016). However, the Union Parishads have nonetheless remained viable and effective local government bodies in Bangladesh (Ahmed, 2016a).

\subsection{Brief History of Partisan Local Government Elections in the World}

There are five types of practice found for electing or selecting representatives for the local government in the world (Alim, 2015). Among these, totally non-partisan elections whereas parties are not allowed to endorse, support and oppose candidates are found mostly; on the other hand, partisan basis election whereas candidates compete in the elections as a party candidate is found very few (Alim, 2015; Humes, 1959). In Malaysia, no local government elections are conducted. During the British rule, local government structures were governed by the commission members who were appointed by the Governor of British (Alim, 2015; Chowdhury, 2015). However, in 1857 and 1858, municipal elections were held to replace the appointment process. After that in 1965, the federal government suspended local government elections due to the emergence clash between Malaysia and Indonesia. Therefore, since 1965 to till; local councilors in Malaysia are appointed by the party in power (Alim, 2015). In the United Kingdom, all local government elections are partisan in character (Chowdhury, 2015; Humes, 1959). Political parties nominate the candidates, selected party candidates can submit their nominations and respective party leaders get opportunity to participate in the election campaigns (Alim, 2015; Humes, 1959). Most local elections in the United States of America are non-partisan. Until 1986, local elections in California were typically non-partisan with provisions for political parties to endorse, support or oppose the candidates (Alim, 2015; Chowdhury, 2015). In 1978, first partisan local government polls were held in West Bengal of India (Alim, 2015; Nath, 2015). In 1994, another thirteen provinces adopted the partisan local polls. But unfortunately, the consequences of that polls was not satisfactory due to massive death of the voters, rigging the votes by the ruling party (Alim, 2015).

In Bangladesh, till 2015 all local body elections was typically non-partisan whereas the candidates couldn't submit nomination along with an authorization from his/her party and the candidates couldn't use the party symbol or the portrait of party leaders while campaigning 
(Alim, 2015, Mojumder, 2015; Nath, 2015). However, parties are seen endorsing and supporting the candidates as well as opposing other candidates. Furthermore, during the election campaign, party slogans and even the name of the party are often used that is not go for the characteristics of non-partisan elections (Alim, 2015; Mojumder, 2015). Globally, partisan and non-partisan elections do not necessarily create barriers in conducting credible elections. In the UK, there is no question about the credibility of partisan local elections (Funkhouser, 2016). In Norway, the local elections are conducted by the existing local government (Alim, 2015).

\subsection{History of Partisan Local Government Elections in Bangladesh}

The history of local government in Bangladesh is more often experimented and used by the then ruling parties (Sarker \& Akber, 2016). According to the constitution of the People's Republic of Bangladesh, article 59 specifically states that "local government in every administrative unit of the Republic shall be entrusted to bodies composed of persons elected in accordance with law." Unfortunately, we have had continuously the local government institutions only at Union level since 1972 (Sarker \& Akber, 2016; Siddique, 2005).

On October 12, 2015 the cabinet approved the drafts of five laws on local governments which allowed registered political parties to nominate candidates in the local body elections (Alim, 2015; Mamun, 2015). It also permitted candidates to use party symbols and even the portrait of their party leaders while campaigning. In the meantime politicians, local government experts and other civil society organisations are in hot debate about the decision of the government to hold local poll on party-line having no discussion with political parties or arranging any referendum to check public opinion (Sarker \& Akber, 2016; Nath, 2015). The politicians, local government experts and other civil society persons opined that the new system of partisan local government polls might obviously destroy the value system carried so long at local level (Sarker \& Akber, 2016; Safi et als., 2015). In previous system, Chairman and Members are elected at Union Parishad on the basis of their family background, tradition, reputation for social work (Sarker \& Akber, 2016). They belong to non-party but elected with massive votes in cognizance of their commendable social works in the locality. The partisan poll will surely drive away these whistle blowers of value system in the locality to be replaced by party followers who might have controversial identity in the society (Safi et al., 2015). Some party candidates might be musclemen to influence the voters by force and creating conflicts and disturbing peace in the locality permanently (Safi et al., 2015). The main opposition of the ruling party 'Bangladesh Nationalist Party' has opposed these partisan local government elections as a political trick with an ill motive (Nath, 2015).

On the other hand, those advocating partisan polls are citing examples of India, UK, and USA where local elections are held with the identity of political parties (Sarker \& Akber, 2016). Even in Bangladesh, local polls like 'City Corporations' and 'Upazila Parishad' elections were held in the recent past with clear political identity of candidates although they used no symbol of party. Thus, it was felt appropriate by the government to go for the partisan polls to bring the democracy to the grassroots level (Sarker \& Akber, 2016). The ruling party 'Bangladesh Awami League' considers demonstrating its popularity at grass-root level 
through this election (Nath, 2015). In independent Bangladesh, first local government election was held in 1973 with non-partisan basis. From the very beginning of independence Bangladesh to the year of 2015, all local government elections was non-partisan, although there were political flavours with many candidates (Karim \& Rashid, 2016). But for the first time in the history of Bangladesh, the government has taken decision to hold all local government elections on partisan basis from 2015 (Mamun, 2015). Following this, $9^{\text {th }}$ Union Parishad elections have been held in 2016 across the country at six phases. This Union Parishad election in Bangladesh has to be first ever experienced of partisan polls. Now it is the time to raise the question how was the partisan Union Parishad poll considering free, fair and credible election under the amended act and what are the consequences of this partisan Union parishad polls on local democracy as well as local social value system?

\section{Purpose of the Study}

The purpose of the study is to explore the first ever experiences of maiden partisan Union Parishad polls and its immediate consequences on electoral process as well as local governance system.

\section{Methodology of the Study}

The study is mainly based on literature review and it is basically a case study where the study tried to explore the experiences of maiden partisan UP polls of Bangladesh. Both of qualitative and quantitative data has also been considered for this study. Data has been collected through secondary sources. The well circulated daily newspapers of Bangladesh i.e. The Daily Prothom Alo, The Daily Star, The Daily New Age, The Daily Independent, The Daily Sun, The Daily Observer, The Daily Ittefaq, The Daily Jugantor, The Daily Kaler Kontho, The Daily Manab Jamin, The Daily Samokal, The Daily Naya Diganto, The Daily Amar Desh, The Daily Amader Somoy has been considered to collect the data. In some cases couple of online newspapers has also been considered for collecting data whereas necessary information was not found as well as for cross checking. Data has also been coded, organized and analyzed with descriptive manner, in some cases tabular or Bar Diagram has been used to present the data.

\section{Discussion and Analyzing}

As per the Article 21(3) of the UDHR (Universal Declaration of Human Rights), "the will of the citizen shall be the basis of the authority of the government and this kind of will shall be expressed through periodic and genuine elections where universal and equal suffrage shall be ensured by secret vote or by equivalent free voting procedures" (Liton, 2016; UDHR, 1948). The United Nations General Assembly in 1948, adopted the UDHR, recognizes the integral role that transparent and open elections play in ensuring the fundamental rights to participatory government (Liton, 2016). International Covenant on Civil and Political Rights adopted by the UN General Assembly in December 1966 also stressed the necessity for free and fair elections (Liton, 2016). Article 3 of the first protocol of the European Convention of Human Rights provides for the right to regular, free and fair elections for establishing and maintaining the foundations of an effective and meaningful democracy governed by the rule 
of law (Liton, 2016).

According to the article 11 of the constitution, "the People's Republic of Bangladesh shall be a democratic country in which fundamental human rights and freedoms and respect for the dignity and worth of the human person shall be guaranteed, and in which effective participation by the people through their elected representatives in administration at all levels shall be ensured" (The Constitution of PRB, 2014; Siddiqui, 2005). In the local government system of Bangladesh, Union Parishad is the lowest tier of the administration and in which effective participation of people must be ensured through their elected representatives. Article 59 of the constitution upholds the spirit stipulated in article 11 by saying that a local government body shall be composed of people elected according to the law (Siddiqui, 2005; Rahman, 1988). Several criterion are used to determine whether an election is free, fair and acceptable ("Marred UP elections", 2016; Mojumder, 2016d): (i) whether the electoral process was inclusive, accurate, based on adult franchise and everyone eligible were enrolled; (ii) those who wanted to be candidates could become candidates; (iii) the elections were competitive and there were alternatives before the voters; (iv) voters could safely go to the voting centers and freely cast their votes; and (v) the whole process was transparent and credible. Following the above criteria and after collecting the relevant information from the daily newspapers on the $9^{\text {th }}$ partisan Union Parishad polls, the following scenario and consequences has been come out.

\subsection{Nomination Business from Grass root to Central}

The nomination trade has been more widespread in the last Union Parishad elections (Mojumder, 2016e). Although the directives issued by the ruling party allowed no role for the Member of the Parliaments (MPs) in the nomination process, but they made the final decision in many cases (Mojumder, 2016e). In most of the cases, committed party activists were deprived and undesirable candidates were nominated due to unwillingness of providing money against nomination (Mojumder, 2016d). Sometimes the relatives or close followers of the party bosses were nominated. There was a open secret rumor that if the candidates get the symbol of 'Boat' (ruling party's symbol), he or she need not campaign for vote, they will win automatically through interference by MPs, rigging the vote by the ruling political activists, applying the muscle-money power of ruling party supporters (Rono, 2016). For that regards the chairman candidates has to expend 12500 to 125000 USD to manage various steps of nomination process (Rashid, 2016a).

Another funny thing is that those who got nomination from Bangladesh Nationalist Party, another competitor of ruling party, they also had to be paid money to get it for holding their own position within the party, although they knew that they will not win in this election (Rono, 2016). Even though the member candidate those need not party nomination had to pay money to keep his/her name under the party chairman candidate (Hossain \& Rashid, 2016). There was an announcement from the party that those who are the rival candidate, the party will expel them, but no one withdrew their candidature. Because the sacrificed leader are not evaluated properly due to nomination business those who have strong influence at grassroots level (Hossain \& Rashid, 2016; Rashid, 2016a). Besides, there was a slogan in this local polls 
that 'money is needed to get nomination, but not for vote' (Rono, 2016). Since the candidate will must win if they get the nomination from the ruling party, the personal honesty and qualifications was not considered in this regard. Even some well qualified; popular, clean imaged candidate could not take part in this election due to nomination business (Khan, 2016a; Hossain \& Rashid, 2016; Mojumder, 2016h; Mojumder, 2016i).

\subsection{Uncontested Elected Chairman}

According to the laws, it is not fault to be elected without contest. History of Bangladesh says that it is very rare case in Union Parishad polls to be elected without voting. But this year has created a history regarding un-contestant elected chairman/members (Mojumder, 2016k). Before that the number of un-contestant elected chairman was 100 in 1988 during the President Ershad regime ("Violence Picture of Union Parishad Election," 2016). In 2011 election, the participated average number of chairman candidates were 6 but in 2016 that was 4 (Mojumder, 2016k). The number of un-contestant chairman during all Union Parishad polls in independent Bangladesh (Chowdhury, 2016b; Karim, 2016) in the following:

Table 1: The number of un-contestant UP Chairman

\begin{tabular}{|l|l|l|l|l|l|l|}
\hline Year & 1988 & 1992 & 1997 & 2003 & 2011 & 2016 \\
\hline Uncontested Elected Chairman & 100 & 04 & 37 & 34 & - & 214 \\
\hline
\end{tabular}

Table 1 shows that uncontested elected number of chairman in the $9^{\text {th }}$ UP polls 2016 were 214 . Among 214 chairmen, only two neutral candidates are elected without any contest, others are from the ruling party (Rono, 2016 ; "Those who alive couldn't go to polling centre due to fear, but dead people casted their vote: Sujon," 2016). In this election, 554 Union Parishads had no chairman candidate of Bangladesh Nationalist Party (BNP), the main competitor of ruling party (Chowdhury, 2016b; Karim, 2016; Mojumder, 2016a). BNP expressed that they didn't find any party member as a contestant in 102 Union Parishads due to the threat of local ruling party leaders (Rono, 2016; "Violence Picture," 2016). Another remarkable things found in this election that there was no competitor (chairman and member candidate) with ruling party in 34 Unions of one district that is first time happened in Bangladesh local polls (Karim, 2016).

\subsection{Obstacles to Submit The Nomination Paper}

Arrest, political case, attack, threat, fear, demonstration of illegal arms was the main obstacles to submit nomination paper by the opposition candidate and rival candidate of the ruling party (Mojumder, 2016k; Sarker, 2015). Those who got nomination from BNP, among them 188 chairman candidates couldn't able to submit their nomination paper due to the obstacles by the ruling party leaders as well as activists ("Violence Picture," 2016). In 102 UPS, the BNP candidates were threatened so that they had to withdraw their nomination ("Union Parishad Election 2016: A Review," 2016). 59 candidates among them was supposed to withdraw their nomination by force during submitting their nomination ("Violence Picture," 2016). BNP claims that ruling party activists prevented their candidates in 83 UPs 
from filling nominations paper (Rashid, 2016a). In many places, the nomination papers of BNP candidates and rival candidates of ruling party were declared "Rejected" by the Election Office showing non-reasonable causes ("Union Parishad Election 2016," 2016). Similar complaints are also made by some partners of the ruling alliance and the rival candidates of the ruling party. Even those who could file their nomination papers were complaining that they were facing various kinds of threats (Mojumder, 2016e). Because of the widespread threats, harassments and prevention to submit nomination papers by the opposition party and rival candidates, 214 chairmen candidates from the ruling party were elected unopposed in this election, which is unprecedented in the history of local polls in Bangladesh (Mojumder, 2016e; Sarker, 2015).

\subsection{Election Frauds With Irregularities}

The festive mood of the polls to the lowest tier of local government was largely marred by electoral irregularities and clashes between the supporters of ruling party and rival candidates ("Election process and UP both are going to be questioned," 2016; Mojumder, 2016d). Various irregularities including widespread stuffing of the ballot box, capture of polling stations, kidnapping the ballot paper, incidents of chase and counter-chase, casting of fake votes, using the illegal arms, cocktail explosion, tackle the voters away from polling centre, to put seal on the ballot openly and intimidation mostly by ruling party Bangladesh Awami League activists marred the maiden partisan elections of Union Parishads were reported during the voting held along party lines (Ahmed, 2016a; "Bloodshed stalks polls," 2016; "Nine killed as violence, rigging mar UP polls," 2016; "Stuffing, violence mar UP polls," 2016; "Violence Picture," 2016).

Even the election officer and law enforcing agencies were involved with vote rigging (Mojumder, 2016k). The election commission postponed the voting of 123 Union Parishads due to massive uncontrolled situation and that was happened between the candidate of ruling party and rival candidate of ruling party (Mojumder, 2016k). Even though the president of Worker's Party of Bangladesh and the minister of Civil Air Force and Tourism, the alliance of ruling party, complained during the election to Election Commission that there is a festive mood of stuffing the vote by the ruling party candidates in UP polls (Karmakar, 2016b; Mojumder, 2016k). Moreover, the activists from Awami League did not allow the opposition candidates' polling agents to enter the polling centers or drove them out of the centers by force after assaulting them ("Union Parishad Election 2016," 2016).

\subsection{Open vote for Chairman, secret vote for Member}

According to the reports of newspaper and the TV, it is clear that the voters did not cast their vote for chairman candidate in 50\% Union Parishads (Chowdhury, 2016b; Karim, 2016a, Mojumder, 2016a). There was a message from the ruling party activists and agents at the polling centre that vote for chairman has been already casted, you can cast your vote for member candidates (Chowdhury, 2016b; Karim, 2016a). Besides that it was a popular slogan during the whole election process that Chairman vote will have to be casted openly but members vote can be casted secretly (Chowdhury, 2016c). The polling agents of ruling party handed the ballot paper to the voters for members candidate only, not for chairman candidates. 


\section{Macrothink}

Most of the presiding and polling officer was reluctant for casting the votes properly (Chowdhury, 2016c; Hossain, 2016e). Various irregularities like to quit the agents of opposition party or rival candidates from the polling centre or not to give opportunity to enter them in polling centre, capture the booth, to put seal on the ballot papers through kidnapping, , to demonstrate the muscle power at the outside of the polling centre was the common phenomenon in most of the UP polls ("Awami Leage 387 in UP election at last," 2016; "Election fraught with irregularities," 2016; "Frustrated UP Election," 2016; Hossain, 2016c; Mojumder, 2016e).

\subsection{Death \& Violence During Polls}

According to $S U J O N^{1}$, the total number of deaths of this maiden partisan Union Parishad polls is 145 and injured 5000 plus people ("Best record of Deaths and Bloodshed," 2016; "Last Phase of UP Election: Deadliest polls end, taking four more lives," 2016; Mojumder, 2016k; "Vote finished with 112 Deaths: 4 more killed in $6^{\text {th }}$ Phase," 2016):

Diagram 1: Total deaths during $9^{\text {th }}$ UP polls

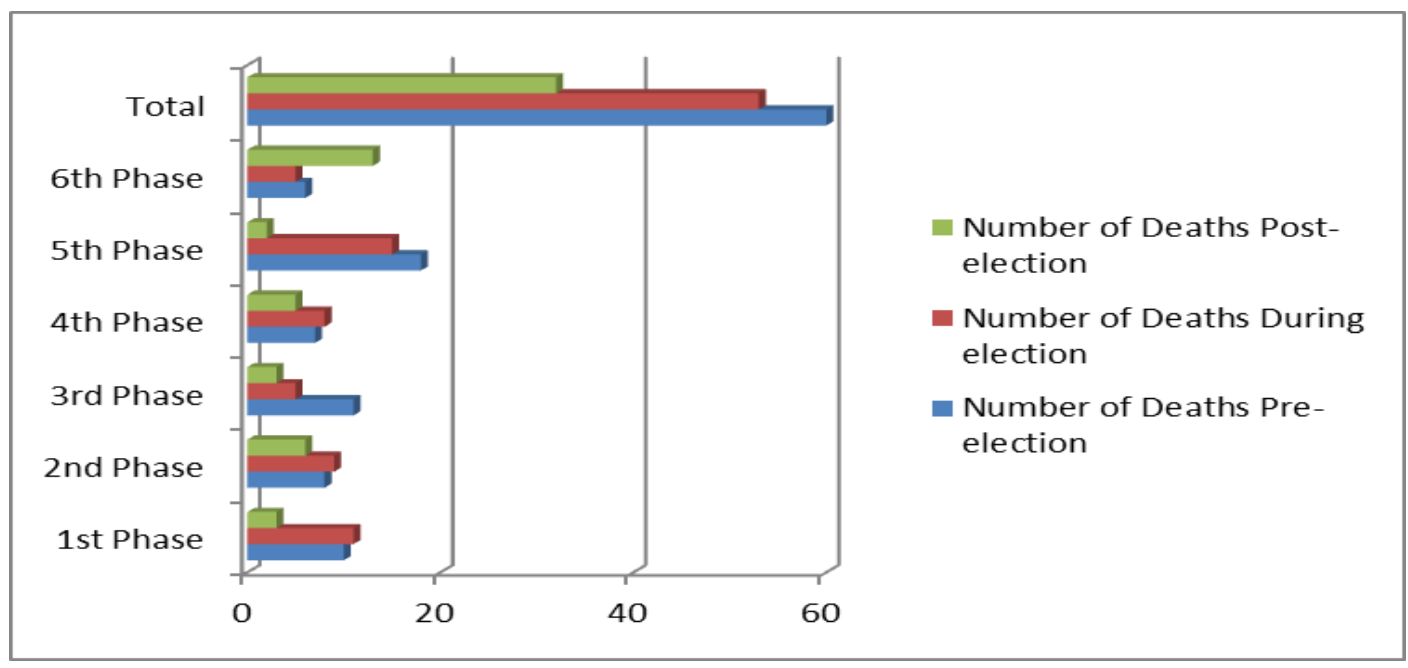

Diagram 1 shows, from the declaration of election to finish the polls in 2016, 145 people were killed. Among them 32 from Chittagong division, 29 from Dhaka division, 20 from Rajshahi division, 17 from Barisal division, 17 from Khulna division, 16 from Mymensingh division, 9 from Rangpur division and 5 from Sylhet division were killed during the whole election process ("Best record," 2016; Chowdhury, 2016a; Islam, 2016; "Last Phase," 2016). Collision has been happened in every districts but the death has been happened in 46 districts among 64 ("Current UP Election is the worst example in the history: Sujon, Dead 101 till now, Injured 8 Thousands," 2016; "Those who alive," 2016; Sabbir, 2016). According to SUJON, 56 persons from ruling party candidate's supporters, 15 supporters from rival candidates of ruling party, 7 persons from BNP, 1 from JP, 1 from Jonosonghoti Party, 3 from neutral, 36 from member candidate's supporters, 1 from police, 25 general people were killed during this polls (Hasan, 2016a; Hossain \& Alam, 2016; Mojumder, 2016b).

\footnotetext{
${ }^{1}$ SUJON means Sushasoner Jonno Nagorik that is one of the top most civil society organizations in Bangladesh working on Governance and Development.
} 


\section{Macrothink}

Total number of deaths of all Union Parishad polls in Bangladesh (Mojumder, 2016c; Sabbir, 2016):

Table 2: The number of deaths in all UP elections

\begin{tabular}{|l|l|l|}
\hline Year & Union Parishad Elections & Number of Deaths \\
\hline 1973 & $1^{\text {st }}$ & 0 \\
1977 & $2^{\text {nd }}$ & 0 \\
1983 & $3^{\text {rd }}$ & 0 \\
1988 & $4^{\text {th }}$ & 80 \\
1992 & $5^{\text {th }}$ & 0 \\
1997 & $6^{\text {th }}$ & 31 \\
2003 & $7^{\text {th }}$ & 23 \\
2011 & $8^{\text {th }}$ & 10 \\
2016 & $9^{\text {th }}$ & 145 \\
\hline
\end{tabular}

To review the death accounts of all previous elections, it is found that this year was the highest death numbers during whole process of local polls. Before that highest death was happened in 1988 during President Ershad regime. It is also found that the collision was inter-political previously but this year it was intra-political especially between the ruling party candidate's supporters and the supporters of rival candidate of ruling party (Mojumder, 2016a).

\subsection{Non-reasonable Vote Casting}

In this election, those voters were alive they could not cast their vote in some cases but unfortunately the death voters casted their vote in some Ups ("Dead People and foreigner casted their vote, EC has been ashamed," 2016; Mojumder, 20161).

Table 3: Lists of over assumed voter casted UPs

\begin{tabular}{|l|l|}
\hline Name of the Ups & Percentage of Casted Vote(\%) \\
\hline Belchari UP, Matiranga Upazila, Khagrachari & 196 \\
Chandon Nagar, Niyamotpur Upazila, Naogaon & 107 \\
Gomti UP, Matiranga Upazila, Khagrachari & 98.6 \\
Fatehpur UP, Nachol Upazila, Chapai Nawabganj & 90 \\
West Chatnai UP, Dimla Upazila, Nilphamari & 92 \\
\hline
\end{tabular}


Nun Khawoa UP, Nageshwari Upazila, Kurigram 93

Chanduriya and Soronjai UP, Tanore Upazila, Rajshahi

90

Talondo UP, Tanore Upazila, Rajshahi

91

There were lot of fake and over-assumed votes in this election. In some cases, the percentage of casted voters was 100 percent (Ahmed, 2016c; Rashid, 2016b). Even though, more than 100 percent vote has been casted in some Ups and some Ups are very close to 100 percent (Ahmed, 2016c). Election Commissioner Mohammad Shah Newaz said that there is no way to cast $100 \%$ vote because there are some voters those who have been already died or living abroad or working other places (Karmaker, 2016b; "Union Parishad Election 2016: EC lost the position," 2016). According to the Election Commission, 85-90 percent vote has been casted in 96 UPs and 80-85 percentage vote has been casted in 175 UPs that is really unprecedented considering the past election records (Ahmed, 2016c; "Dead People," 2016).

Table 4: Lists of UPs where non-believable voting casted between two major parties

\begin{tabular}{|l|l|l|}
\hline Name of UPs & Bangladesh Awami League & Bangladesh Nationalist Party \\
\hline Matu Bhuiyan & 9084 & 164 \\
Sindurpur & 14,086 & 339 \\
Rajapur & 13,063 & 494 \\
East Chandrapur & 9,787 & 364 \\
Yakubpur & 9,007 & 235 \\
\hline
\end{tabular}

In some Unions, the casted voter between two major party candidates were unreasonable considering the past history of local polls election ("Violence in UP Election: CEC demands to change the political culture," 2016). In this election, $31.29 \%$ of votes were secured by the neutral candidates that are the highest for neutral candidates in the history of any polls held in Bangladesh ("Union Parishad Election 2016," 2016). One of the largest party BNP managed to secure only $18.78 \%$ votes and ruling party the Awami League secured $47.28 \%$, whereas the neutral candidates were in second position (31.29\%) that is very hard to believe (Khan, 2016c; "Union Parishad Election 2016," 2016; "Worst UP Election," 2016).

\subsection{Conflict among MP vs Mayor vs Upazila Chairman}

It is observed during the whole election process that there was a big mismatch among Zilla Parishad administrator, Local MP, Upazila Parishad Chairman, Mayor of Pourashava, Upazila Committee, Zilla Committee of the ruling party ("Conflict among ruling party creates violence," 2016; Hasan, 2016a; Hossain \& Alam, 2016; "Last Phase of Union Parishad Election: Two rival candidate in every three of Awami League," 2016; "Power competition between MP and Mayor, The voters are in fear," 2016). The main reason was that if the nomination can be ensured for their own allied candidate, he/she will must win by hook 
or by crook (Hossain, 2016c). It means that there was no equal opportunity to compete by the opposition party candidate. The administrator of Zilla Parishad didn't listen to the opinion of Local MPs, Local MPs ignored the opinion of Zilla Parishad administrator, even though Upazila ruling party committee didn't follow the Zilla committee advice to select the party candidates (Hasan, 2016a).

Most of the collision has been happened by the dominance of local influential ruling party members (Alam, 2016). Local MP tried to control his/her dominance at local level through providing nomination of his/her close person in most of the cases ("Conflict among," 2016; "Power competition," 2016). For that regards, the candidate of other parties was not getting level playing field during the whole election process (Hasan \& Khan, 2016). The conflict between local MP and Local Upazila Parishad Chairman was found in various constituency. In some places, Upazila Chairman has hope to become MP candidate in next election. For that regards, the running MP tried to capture all UP chairman for his/her allied candidates through dominating over Upazila Parishad Chairman (Hossain, 2016b; Hossain, 2016e; Mojumder, 2016g). To fulfill their desire, rival candidate was found in most of the cases, either the rival candidate is in favor of MPs or in favor of Upzila Parishad Chairman. As a result, the collision has been happened and deaths have been ensured in various places between the clash of ruling party candidate and rival candidates (Hasan \& Khan, 2016; Mojumder, 2016j; "Power competition," 2016).

\subsection{Reluctant Election Commission}

According to the article 126 of Bangladesh Constitution, all executive bodies should cooperate the election commission for maintaining their responsibilities properly. The sub section 4 of the article 118 said that the election commission will be independent to do their job and the election commission will do their job following the constitution and the existing laws (The Constitution of PRB, 2014). According to the verdict from the Appellate division of Supreme court between the case of Altaf Hossain and the case of Abul Kashem (DLR 45,1993), the election commission can take any necessary actions whatever they need to conduct a free, fair and transparent election, even though they can add some rules and regulations to follow this (Mojumder, 2013; Mojumder, 2016c). Unfortunately, in spite of enough power, the commission was reluctant to execute their power (Ahmed, 2016b).

Clashes between rival and party candidates, numerous incidents of storming of polling stations, ballot stuffing and snatching of ballot boxes were reported in the media during the election day (Khan, 2016b; "Marred UP," 2016; Mojumder, 2016c). The Election Commission remained silent spectators to the shameless irregularities and violence conducted by the ruling Awami League ("Electoral system collapsed due to toothless EC," 2016; "Marred UP," 2016; Mojumder, 20161; Rashid, 2016b). The Election Commission didn't take any action against any irregularity and violence except for very few cases although having thousands of specific complaints ("Union Parishad Election 2016,", 2016). Among 36 thousand voting centers in the country, the Commission withheld voting in only 346 centers, whereas most of the centers were taken over by the ruling Awami League ("Electoral System," 2016; Mojumder, 2016i; Rashid, 2016b). Although there were 1500 plus complaints 
from the candidates to the election commission, they took very few number of cases into consideration ("Election Commission is accusing others after failing to conduct free and fair election: Sujon," 2016; Karmakar, 2016b). Instead of having enough power, they advised the candidates to go to the court (Rashid, 2016b). At last, the election commission issued a letter three times to Home ministry that there is no sound environment to conduct free and fair election ("Electoral system," 2016; Rashid, 2016b). But there was no response from the ministry. It shows clearly that the Election Commission has independent power in paper but they, somehow, were controlled by the ruling party.

\subsection{Inactive of Law Enforcing Agencies}

The ballot was stuffing most of the places in favor of the ruling party's candidate in front of the law enforcing agencies (Ahmed, 2016b; "Capturing with great entertainment is going on in UP," 2016; "Election process," 2016). In some places, the armed cadres submitted the sealed ballot paper to the presiding officer after kidnapping the ballot box from the polling centers ("Capturing with," 2016). According to the field officer of election commission secretariat; Police, Bangladesh Border Guard (BGB), Returning Officer from the executive department, Presiding officer, Polling Officer cooperated the ruling party candidate to capture the centre or rigging the votes (Ahmed, 2016a; Ahmed, 2016b; Hossain \& Alam, 2016; Rashid, 2016b; "Union Parishad Election 2016: EC lost the position," 2016). Even though law enforcing agency were involved to attack on the opposition party supporters ("Union Parishad Election," 2016). Before every election, the Ministry of Home Affairs usually asks the legal firearms owners to deposit their arms at the local police station, but it did not happen this time (Ahmed, 2016a; Mojumder, 20161; Rashid, 2016b; "Union Parishad Election 2016,", 2016). They were not only inactive to take actions against irregularities but also they were involved with the rigging process of votes ("Union Parishad," 2016). For that regards, the causalties was too high in this election.

\subsection{Threatens to Social Harmony}

The secretary general of Bangladesh Nationalist Party Mr. Mirza Fakhrul Islam Alamgir complained that the government is responsible for creating terrorist activities at the grassroot levels through introducing the election on party symbols (Khan, 2016c; Mojumder, 2016g). There was a clear dividation between the village people and society through this partisan election (Karim \& Rashid, 2016). Although there were a long history of election at local level, mutual relationship and social cohesiveness were found among the rural society (Hasan, 2016b). The major negative thing from this election is that it has been created conflicting relationships and hampered the long historical sound traditions among the villagers (Khan, 2016c; Mojumder, 2016b; Mojumder, 2016g). Although the rural value and ethics was destroying from day by day, this partisal local polls has added the last pail in the dead bodies (Khan, 2016b). Through this partisan local polls; unethical competition, blind patriarchy, partiocracy has been increased at the grassroots levels that is the threat to maintain social harmony at local level (Mojumder, 2016g). 


\subsection{Lose the People's Trust And Credibility To Local Polls}

The election observer BROTI opined that un-trust situation has been created among the general people on the election process due to the huge casualties, irregularities etc.(Karim \& Rashid, 2016). For this un-trust situation, the imbalance of power can be created at the grassroots levels. The democracy can be faced problem for this unwanted situation (Karim \& Rashid, 2016; "Union Parishad Election," 2016). Major problem was found that the people will lose their interest on the electoral system (Karim \& Rashid, 2016). The total electoral process has been broken due to the illegal power using by the ruling party and the ineffectiveness of the election commission (Khan, 2016b; Rono, 2016). The election commission seems to the part of ruling party (Ahmed, 2016b). If this sort of party dominated monopoly election continues, the trust and credibility of the rural local people will be zero on the election process (Khan, 2016b; Rono, 2016).

\section{Conclusions}

The party-system of Bangladesh is not only non-democratic but also 'party-archy' (Dolbazi), by which political party those are in power systematically politicizes every institution and tries to create strong control by distributing authorities to their party men by exercising state machineries and resources (Chowdhury, 2015). In this context, the chief executives those who will be elected under the new arrangement, obviously they will be the party men and they would have a strong connection with the central government (Chowdhury, 2015). For that regards, the balance of power between the legislature and executive would be collapsed. From the above discussion it is clear that local MP those who is the part of legislature interferences in the nomination process of local government election that will impair local government system and the local governance (Chowdhury, 2015; Rashid, 2015). Another serious problem is found that local judicial system will be chaired by a partisan person those who have strong possibility to make decision in favor of his/her own party activists (Chowdhury, 2015). Apprehensions are that these local partisan leaders are going to be the queue for national level politics competing between existing Upazila Chairman or MPs (Rashid, 2015). It may create confrontation among the party leaders at the local level and may pave the way for a dangerous dividation at the grassroots level (Chowdhury, 2015; "EC failed to conduct free and fair election,", 2015; Rashid, 2015; Stone, 1980).

Issues unveiled from maiden partisan UP polls:

- Union Parishad election 2016 was the most violent election in the history of Bangladesh. Terror, fear, threats and panic was spread out instead of festive mood across the country. The ruling Awami League snatched the election by using ruling \& muscle power. Except for few places, the polls were a complete unfair and forgery all over the country. Voters could not cast their votes according to their will and rights, especially for the post of chairman.

- The decision to hold Chairman Elections on the basis of party symbols and member elections without party symbols created a conflicting and ambiguous situation in the local polling system. 
- There was a common slogan across the country during the last UP polls "Open vote for Chairman, Secret for Member candidates".

- Number of deaths created a record in the history of election in Bangladesh, total deaths were 145 and injured 5000 plus people.

- This election also created history in the record of 214 UP Chairman has been elected un-contestant. Among them only 2 neutral UP chairman has been elected without contest, others from ruling Awami League.

- Election violence occurred mostly between the Awami League and their party rival candidates, not against with the opposition parties.

- It was open secret that victory is secured with Awami League's "Boat" symbol, so that the Awami League leaders became desperate to get nomination by hook or by crook that resulted a huge nomination trade, conflicts and violence within the party.

- It was very shame for the election commission that the rate of cast votes was more than $100 \%$ in some polling centers.

- Presiding \& Polling Officers along with law enforcement agencies were found stuffing ballot boxes while ruling party candidates used firearms to drive away the representatives of the opposition party or rival candidates of the ruling party.

- Election Commission of Bangladesh published results after each phase of UP election that affects on the next phases of the election. But in India where election is held in couple of phases, final result is declared after the completion of all the phases so that the result of one phase cannot affect or influence on others.

- This election has undoubtedly proved that the Election Commission is inefficient, inactive, spineless, partisan and completely incapable of conducting a free, fair \& credible election. This commission was not willing to execute and implement its own legal authority. They are used to look for what the government wishes \& demands and they act accordingly.

- This election clearly divided the local people into partisan basis Although there were a long history of election at local level without partisan, mutual relationship and social cohesiveness among the rural society were observed, this election has been clearly divided the local people by forcing to choose the party candidates.

Holding local body elections under party banners is not going to be a unique practice in Bangladesh, as partisan local government elections is found in many countries like Switzerland, Malaysia, the Philippines and the United Kingdom (Rahman, 2015). Though it is too early to conclude on the party-based election of Union Parishads, the developments centering round the ongoing Union Parishad elections are sending wrong signals. The volume of violence, the complaints of nomination business, silent role of Election Commission as well as fraught in the electoral system have been unpleasant (Khan, 2016c; Mojumder, 2016k). The intention behind the party-based model of Union Parishad elections 
is thus being questioned strongly (Rahman, 2015).

At this moment, the ruling party MPs already dominates over the Upazila Parishads. Now, if the remaining local government bodies are also captured by partisan elections, ruling party will avail the opportunity to have control over all political institutions, which would be absolutely threatening for sound democratization and stabilization (Mamun, 2015). Local Government experts are showing complete agreement to the fact that such step would reduce the scope of empowering the local government bodies to address the local issues in consultation with the mass people of diverse opinion instead of depending on the government's orders ("Local bodies election on party line means party dictatorship all the way," 2016). Unfortunately this election has conveyed a clear message that no free, fair and transparent election is possible under the partisan Election Commission and the party government considering the existing political culture of Bangladesh (Khan, 2016b). To save long historical democracy at the local level; a free, fair, neutral and transparent Election Commission is now the top-most priority whereas party government would not have any administrative or financial control over Election Commission (Khan, 2016b; Mojumder, 2016k; Rono, 2016). Besides that Bangladesh as a developing country is not well prepared and structured to conduct free, fair and credible local government election under party government using party symbol holding the existing confrontational and prismatic societal characteristics into political system (Funkhouser, 2016; Hossain, 2016d; Khan, 2016b; Riggs, 1964). Moreover the political scientists as well as the practitioners would have to wait to observe how the party backed elected representatives by faulty election perform in the local development and maintain the long lasting harmonious relationship among the local peoples as party men.

\section{References}

10 killed as violence, rigging mar UP polls. (2016, March 23). The Daily New Age. http://newagebd.net/214267/eight-dead-as-violence-rigging-mar-up-polls/

10 killed in UP violence. (2016, March 23). The Daily Star. http://www.thedailystar.net/frontpage/5-killed-violence-1198312

4th phase UP polls see deadly clashes, ballot-stuffing. (2016, May 08). The Daily Star. www.thedailystar.net/country/violence-irregularities-mark-4th-phase-polls-1220260

Ahmed, K. (2016a, June 06). EC was promising to prove the less important of human life (In Bengali). The Daily Prothom Alo. www.prothom-alo.com/bangladesh/article/879694/

Ahmed, N. (1987). Democracy and Rural Local Government in Bangladesh. Quarterly Journal of All India Institute of Local Self Government. LVIII: 2, Page 479-492.

Ahmed, R. (2016b, May 02). Government and EC has vanished the electoral system (In Bengali). The Daily Amader Somoy. http://www.amadershomoys.com/newsite/2016/04/09/565835 


\section{I Macrothink}

Journal of Public Administration and Governance ISSN 2161-7104 2017, Vol. 7, No. 1

Ahmed, R. (2016c, April 27). Spotted Local Polls, 196\% Vote Casting (In Bengali). http://banglamail24.com/news/148118

Ahmed, T. (1991). Politics and the Development at the Grassroots: A Study of Local Leadership in Bangladesh. Politics, Administration and Change. 16, Page 29-44.

Alam, M. (2016, June 01). Violence in UP Election: Own party activists is killed by Awami League. The Daily Prothom Alo. http://www.prothom-alo.com/opinion/article/875056/

Alim, M. A. (2015, October 28). Local Government Polls: Partisan vs Non-Partisan. The Daily

Star.

http://www.thedailystar.net/op-ed/politics/local-government-polls-partisan-vs-non-partisan-16 $\underline{3177}$

Awami Leage 387 in UP election at last (In Bengali). (2016, March 23). The Daily Prothom Alo. http://www.prothom-alo.com/bangladesh/article/807733/

Awami League got 9084 \& BNP 164 vote in One UP of Dagonbhuyan (In Bengali). (2016, May 29). The Daily Jugantor. http://www.jugantor.com/online/country-news/2016/05/28/14420

Best record of Deads and Blood shed (In Bengali). (2016, June 06). The Daily Sangram. http://www.dailysangram.com/post/237491

Bloodshed is going on in the name of Election (In Bengali). (2016, May 29). The Daily Jugantor. http://www.jugantor.com/online/politics/2016/05/29/14483

Bloodshed stalks polls. (2016, April 01). The Daily Star. http://www.thedailystar.net/frontpage/bloodshed-stalks-polls-1202569

Bodruddoza. (2008, August 11). Partisan vs Non-partisan election for local governments. The Daily Prothom Alo. https://bdoza.wordpress.com/2008/08/13/

Cabinet takes decision to hold local elections on party basis. (2015, Oct 12). Bangladesh Awami League. http://www.albd.org/index.php/updates/news/18-updates/news/3059

Capturing with great entertainment is going on in UP (In Bengali). (2016, April 03). Bangla Tribune. http://www.banglatribune.com/national/news/92967/

Choudhury, D. (2015, Dec 22). Local government elections in Bangladesh and democracy. The Daily New Age. http://newagebd.net/186396/local-government-elections-in-bangladesh-and-democracy/

Chowdhury, K. R. (2016a, May 27). Violence at Record Level in Local Voting in Bangladesh. Benar News. http://www.benarnews.org/english/news/bengali/politics-violence-05272016171144.html Chowdhury, M. H. (2016b, May 24). Record of Uncontested Election (In Bengali). Bdnews24.com. http://bangla.bdnews24.com/bangladesh/article1156527.bdnews

Chowdhury, S. (2016c, March 31). Open for Chairman, Secret for Member (In Bengali). The 
Daily Kaler Kontho. http://www.kalerkantho.com/online/country-news/2016/03/31/342317

Conflict among ruling party creates violence (In Bengali). (2016, May 30). The Daily Prothom Alo. http://www.prothom-alo.com/bangladesh/article/872839/

Current UP Election is the worst example in the hoistory: Sujon, Dead 101 till now, Injured 8 Thousands (In Bengali). (2016, May 26). The Daily Naya Diganto. http://www.dailynayadiganta.com/detail/news/121985

Dead 101 in UP Election Violence: Sujon (In Bengali). (2016, May 26). The Daily Prothom Alo. http://www.prothom-alo.com/bangladesh/article/869122/

Dead People and foreigner casted their vote, EC has been ashamed (In Bengali). (2016, May 12). Sheershanewsbd.com. http://www.sheershanewsbd.com/2016/05/12/127519

Death \& violence during polls. (2016, April 02). The Daily Star. http://www.thedailystar.net/editorial/death-and-violence-during-polls-1202914

EC failed to conduct free and fair election (In Bengali). (2015, December 14). The Daily Prothom Alo. http://www.prothom-alo.com/bangladesh/article/711970/

Election Commission is accusing others after failing to conduct free and fair election: Sujon (In Bengali). (2016, June 05). The Daily Amar Desh. http://www.sheershanewsbd.com/2016/06/05/130564

Election fraught with irregularities. (2016, April 25). The Daily Star. http://www.thedailystar.net/editorial/elections-fraught-irregularities-1213924

Election process and UP both are going to be questioned (In Bengali). (2016, March 24). The Daily Prothom Alo. http://www.prothom-alo.com/bangladesh/article/808552/

Electoral system collapsed due to toothless EC. (2016, June 01). The Daily Star. http://www.thedailystar.net/city/electoral-system-collapsed-due-toothless-ec-1232569

Electoral violence: 2 more people killed. (2016, April 25). The Daily New Age. http://newagebd.net/224513/post-poll-violence-2/

First Phase UP Polls: EC to prosecute 65 chairman candidates. (2016, March 24). The Daily New Age. http://newagebd.net/214560/first-phase-up-polls/

Frustrated UP Election. (2016, March 24). The Daily Prothom Alo. http://www.prothom-alo.com/opinion/article/808159/

Funkhouser, M. (2016). The Poisoning of Our Politics: Partisan Elections , Governing: The States and Localities. http://www.governing.com/gov-institute/funkhouser/gov-partisan-elections.html

Hasan, M. \& Khan, H. R. (2016, May 30). 117 killed in UP Election, Interference of MPs (In Bengali). The Daily Jugantor. http://www.jugantor.com/online/national/2016/05/30/14513/

Hasan, S. (2016a, June 15). UP Election: Awami League also advance in terms of Killing list 
(In Bengali). The Daily Prothom Alo. http://www.prothom-alo.com/opinion/article/888841/

Hasan, S. (2016b, May 07). What did we want such election? (In Bengali). The Daily Prothom Alo. http://www.prothom-alo.com/opinion/article/850938/

Hossain, A. \& Alam, S. (2016, June 15). Most of the deads from Awami League in Deadliest Vote (In Bengali). The Daily Prothom http://www.prothom-alo.com/bangladesh/article/888226/

Hossain, A. \& Rashid, A. (2016, May 12). Money needed for nomination, not for vote (In Bengali). The Daily Prothom Alo. http://www.prothom-alo.com/bangladesh/article/856363/

Hossain, A. (2016a, January 09). AL in a dilemma over partisan UP polls. The Daily Prothom Alo.

http://en.prothom-alo.com/bangladesh/news/91285/AL-in-a-dilemma-over-partisan-UP-polls

Hossain, A. (2016b, October 14). Partisan local polls based on many equations (In Bengali). The Daily Prothom Alo. http://en.prothom-alo.com/bangladesh/news/82559/

Hossain, A. (2016c, May 31). Union Parishad Election: Who is responsible for so many deads (In Bengali). The Daily Prothom Alo. http://www.prothom-alo.com/bangladesh/article/873706/

Hossain, B. (2016d, June 05). Hoping such type of Election will not come again (In Bengali). The Daily Manab Zamin. http://mzamin.com/article.php?mzamin=17047

Hossain, S. (2016e, June 06). How was the Election, Who is responsible for the deads? (In Bengali). The Daily Prothom Alo. http://www.prothom-alo.com/opinion/article/879214/

Humes, S. (1959). The structure of local governments throughout the world: A Comparative study. Martinus Nijhoff, The Hague of Netherlands, ISBN: 978-94-015-0423-2

Islam, S. (2016, May 30). Killed 111: Mass Violence Election in the history (In Bengali). The Daily Naya Diganto. http://www.dailynayadiganta.com/detail/news/122980

Karim, R. \& Rashid, A. (2016, June 06). The Evaluation of Political Parties: The Electoral System has been missmatched (In Bengali). The Daily Prothom Alo. http://www.prothom-alo.com/bangladesh/article/879667/

Karim, R. (2016a, June 06). Dhaneer Shees was not in 550 Ups (In Bengali). The Daily Prothom Alo. http://www.prothom-alo.com/bangladesh/article/879931/

Karim, R. (2016b, June 15). From the very beginning BNP was inactive (In Bengali). The Daily Prothom Alo. http://www.prothom-alo.com/bangladesh/article/888220/

Karmakar, P. (2016a, June 01). Checking Violence in Union Parishad Polls. The Daily Star. http://www.thedailystar.net/city/ec-shrugs-just-sending-letters-home-ministry-1232677

Karmakar, P. (2016b, May 31). EC receives scores of complaints. The Daily Star. http://www.thedailystar.net/backpage/ec-receives-scores-complaints-1232083 
Khan, M. R. (2016a, May 30). Blooded Election: Compare to West Bengal (In Bengali). The Daily Prothom Alo. http://www.prothom-alo.com/opinion/article/872272/

Khan, M. R. (2016b, May 13). Party Union Parishad Polls should be banned (In Bengali). The Daily Prothom Alo. http://www.prothom-alo.com/opinion/article/857563/

Khan, M. R. (2016c, April 01). Where is UP election taking to us? (In Bengali). The Daily Prothom Alo. http://www.prothom-alo.com/opinion/article/816574/

Last Phase of Union Parishad Election: Two rival candidate in every three of Awami League (In Bengali). (2016, June 01). The Daily Prothom Alo.

Last Phase of UP Election: Deadliest polls end, taking four more lives. (2016, June 05). The Daily Star. http://www.thedailystar.net/frontpage/deadliest-polls-end-taking-three-more-lives-1234594

Liton, S. (2016, May 30). Bloodshed makes mockery of polls. The Daily Star. http://www.thedailystar.net/frontpage/bloodshed-makes-mockery-polls-1231351

Local bodies election on party line means party dictatorship all the way. (2016, June 04). The Daily New Nation. http://thedailynewnation.com/news/70234/

Mamun, S. (2015, October 13). Local govt polls to become partisan. Dhaka Tribune. http://archive.dhakatribune.com/bangladesh/2015/oct/13/local-govt-polls-become-partisan

Marred UP elections. (2016, March 24). The Daily Star. http://www.thedailystar.net/editorial/marred-elections-1198534

Mojumder, B. A. (2013, March 17). Which way towards free, fair and meaningful elections? The Daily Star. http://www.thedailystar.net/news/which-way-towards-free-fair-and-meaningful-elections

Mojumder, B. A. (2015, October 18). What is the rationale of partisan local government elections? The Daily Star. http://www.bamajumdar.com/2015/10/what-is-rationale-of-partisan-local.html

Mojumder, B. A. (2016a, May 30). A Review on Union Parishad Election (In Bengali). http://www.bamajumdar.com/2016/05/blog-post_54.html

Mojumder, B. A. (2016b, June 06). As it, this is an election of bad dream (In Bengali). The Daily Jugantor. http://www.jugantor.com/sub-editorial/2016/06/06/36716/

Mojumder, B. A. (2016c, June 05). Conflicting politics create violence in election (In Bengali). The Daily Ittefaq. http://www.ittefaq.com.bd/print-edition/drishtikon/2016/06/05/123712.html

Mojumder, B. A. (2016d, March 20). Faulty Election, Damage Democracy (In Bengali). The Daily Prothom Alo. http://www.bamajumdar.com/2016/03/blog-post.html

Mojumder, B. A. (2016e, March 28). Flawed elections will damage our democracy. http://www.bamajumdar.com/2016/03/flawed-elections-will-damage-our.html 
Mojumder, B. A. (2016f, May 10). Fourth Phase of UP Election: Violence and Irregularities continue (In Bengali). The Daily Amader Somoy. http://www.bamajumdar.com/2016/05/blog-post_30.html

Mojumder, B. A. (2016g, January 31). Government will carry violence in door to door (In Bengali). http://www.bamajumdar.com/2016/01/blog-post_31.html

Mojumder, B. A. (2016h, May 30). Mass Bloodshed in Union Parishad Election (In Bengali). The Daily Jugantor. http://www.jugantor.com/sub-editorial/2016/05/30/35004/

Mojumder, B. A. (2016i, May 12). Review on Union Parishad Election (In Bengali). The Daily Ittefaq. http://www.ittefaq.com.bd/print-edition/drishtikon/2016/05/12/119182.html

Mojumder, B. A. (2016j, May 30). Union Parishad Election with Mass Blood Shed (In Bengali). http://www.bamajumdar.com/2016/05/blog-post_46.html

Mojumder, B. A. (2016k, June 22). Union Parishad: Will faulty election produce right result? (In Bengali). The Daily Prothom Alo. http://www.prothom-alo.com/opinion/article/895135/

Mojumder, B. A. (20161, May 30). UP Election: EC is sending wrong information to the Voters (In Bengali). http://www.bamajumdar.com/2016/05/blog-post.html

Mojumder, B. A. (2016m, February 28). UP Election for Hopes and Frustration (In Bengali). The Daily Samakal. http://bangla.samakal.net/2016/02/28/195983

Mojumder, B. A. (2016n, May 30). Who is misleading whom? http://www.bamajumdar.com/2016/05

Nath, D. K. (2015, November 24). Partisan local polls and challenges for political parties. The Daily Independent. http://www.theindependentbd.com/home/printnews/24302

Nine killed as violence, rigging mar UP polls. (2016, April 01). The Daily New Age. http://newagebd.net/216676/8-killed-as-violence-rigging-mar-up-polls/

Post-Poll Violence : 55 injured, 20 houses vandalised. (2016, April 02). The Daily New Age. http://newagebd.net/216987/post-poll-violence/

Power competition between MP and Mayor, The voters are in fear (In Bengali). (2016, June 03). The Daily Prothom Alo. http://www.prothom-alo.com/bangladesh/article/876892/

Quddusi, K. A. (2016, May 16). Union Parishad: Progress and Partisan Elections. The Daily Sun.

http://www.daily-sun.com/post/136786/Union-Parishad:--Progress-and-Partisan-Elections-

Rahman, M. (2015, October 15). Political make-up of local polls. Dhaka Courier. http://www.dhakacourier.com.bd/political-make-up-of-local-polls/

Rahman, M. M. (1988). Local Self-Government in Bangladesh. Pathya Pustak Prakashan, Rajshahi, Bangladesh (In Bangla).

Rashid, A. (2016a, June 15). Nomination Business from Grassroot to Central (In Bengali). 
The Daily Prothom Alo. http://www.prothom-alo.com/bangladesh/article/888199/

Rashid, H. (2015, December 14). EC is not maintaining it's own formulated rules (In Bengali). The Daily Prothom Alo. http://www.prothom-alo.com/bangladesh/article/711865/

Rashid, H. (2016b, June 15). Election Commission was inactive (In Bengali). The Daily Prothom Alo. http://www.prothom-alo.com/bangladesh/article/888217/

Riggs, F.W. (1964). Administration in developing countries; the theory of prismatic society. Houghton Mifflin, Boston, USA.

Rono, H. A. (2016, June 08). Electoral System: We don't want such type of election (In Bengali). The Daily Prothom Alo. http://www.prothom-alo.com/opinion/article/881458/

Sabbir, M. (2016, May 28). Deadliest Election in the history of Bangladesh (In Bengali). $B B C$ Bangla. http://www.bbc.com/bengali/news/2016/05/160528

Safi, S., Ahmed. M \& Tushar, T. F. (2015, October 22). Partisan Local Polls: AL thinks positive, BNP questions motive. The Daily Sun. http://www.daily-sun.com/post/85263/

Sarker, F. H. \& Akber, F. (2016, May 17). Questioning partisan system in UP polls. The Daily Observer. http://www.observerbd.com/2016/05/17/151797.php

Sarker, S. (2015, October 14). Government wants to restore one-party rule with partisan local polls: BNP. Nirapad News. http://www.nirapadnews.com/english/2015/10/14/news-id:37185/

Siddiqui, K. (2005). Local Government in Bangladesh. The University Press Limited, Dhaka, Bangladesh. Revised $3^{\text {rd }}$ edition.

Stone, C. N. (1980). "Systemic Power in Community Decision Making: A Restatement of Stratification Theory." The American Political Science Review 74:978-90.

Stuffing, violence mar UP polls. (2016, April 24). The Daily New Age. http://newagebd.net/224159/stuffing-intimidation-violence-mar-3rd-phase-up-polls/

Tepper, E. (1996). Changing Patterns of Administration in Rural East Pakistan. Michigan State University, USA.

The Constitution of (PRB) the People's Republic of Bangladesh. (2014). Legislative and Parliamentary Affairs Division. Ministry of Law, Justice and Parliamentary Affairs.

This kind of election is our beyond expectation, Even people didn't expect so. (2016, June 05). Taza Khobor News. http://www.taza-khobor.com/bd/politics/64685-2016-06-05-07-44-44?q=12

Those who alive couldn't go to polling centre due to fear, but dead people casted their vote: Sujon (In Bengali). (2016, June 16). Sheershoa News. http://www.sheershanewsbd.com/2016/06/16/131880

Union Parishad Election 2016: A Review. (2016, July 19). Bangladesh Nationalist Party. http://en.bnpbangladesh.com/2016/07/19/union-parishad-election-2016-a-review/ 


\section{Macrothink}

Journal of Public Administration and Governance

ISSN 2161-7104

2017, Vol. 7, No. 1

Union Parishad Election 2016: EC lost the position (In Bengali). (2016, May 29). The Daily Prothom Alo. http://www.prothom-alo.com/bangladesh/article/871924/

Union Parishad Election: 4 More Deads, Finished Deadliest Polls (In Bengali). (2016, June 05). The Daily Prothom Alo. http://www.prothom-alo.com/bangladesh/article/878725/

Universal Declaration of Human Rights. (1948)

UP Election with party symbol has been entered terrorism at local level (In Bengali). (2016, June 06). The Daily Prothom Alo. http://www.prothom-alo.com/bangladesh/article/879970/

Violence lessens, not irregularities. (2016, April 24). The Daily Star. http://www.thedailystar.net/frontpage/violence-lessens-not-irregularities-1213636

Violence Picture of Union Parishad Election (In Bengali). (2016, June 15). The Daily Prothom Alo. http://www.prothom-alo.com/bangladesh/article/888229/

Vote finished with 112 Deads: 4 more killed in $6^{\text {th }}$ Phase (In Bengali). (2016, June 06). The Daily Kaler Kontho. http://www.kalerkantho.com/print-edition/first-page/2016/06/05/366140

World Bank, United Cities and Local Governments. (2008). Decentralization and local democracy in the world: First Global Report, USA.

Worst Election has been ended (In Bengali). (2016, June 05). Maghna News. http://amarbangladeshonline.net/index.php/details/politics/2084\#sthash.0ruMjFUT.P11m92Js. dpbs

Worst UP Election in the history of 150 years: Sujon (In Bengali). (2016, June 17). The Daily Manab Zamin. http://www.mzamin.com/article.php?mzamin=18927

\section{Copyright Disclaimer}

Copyright for this article is retained by the author(s), with first publication rights granted to the journal.

This is an open-access article distributed under the terms and conditions of the Creative Commons Attribution license (http://creativecommons.org/licenses/by/3.0/).

\footnotetext{
${ }^{\mathrm{i}}$ Lowest tier of rural local government in Bangladesh

ii 'Ward' consists of couple of villages that is also small part of Union Parishad.

iii Zila Parishad is the top tier of rural local government in Bangladesh.

iv Mid-tier of rural local government in Bangladesh whereas partisan elected representatives exist.
} 